\title{
Effects of Incubation Temperature on Rheological Behavior of Hydrogenated Yolk Lecithin Dispersed in Water
}

\author{
Teruo Horiuchi ${ }^{*}$, Yoko Imai ${ }^{2}$ and Kazuo Tajima ${ }^{2}$ \\ ${ }^{1}$ Material Science Research Center, Lion Corporation \\ (13-12, Hirai 7-Chome, Edogawa-ku, Tokyo 132-0035, JAPAN) \\ ${ }^{2}$ HRC, Department of Chemistry, Faculty of Engineering, Kanagawa University \\ (3-27-1 Rokkakubashi, Kanagawa-ku, Yokohama 221-8686, JAPAN)
}

Edited by M. Yonese, Nagoya City Univ., and accepted March 1, 2002 (received for review December 10, 2001)

\begin{abstract}
The effects of temperature on hydrogenated yolk lecithin (HYL) dispersion were determined based on examination of flow curves and shear-jumps in oscillation rheometry, particle size, polarized microscopy and DSC.

Based on the results obtained, the following conclusions were drawn;

1) Temperature dependence of complex viscosity $\left(\eta^{*}\right)$ for HYL-40 and HYL-60 dispersions prepared at $40^{\circ} \mathrm{C}$ and $60^{\circ} \mathrm{C}$ respectively as incubation temperatures indicated features characteristic of complex viscosity at $50^{\circ} \mathrm{C}$, this temperature being related to that of the gelliquid crystal transition of HYL, HYL-50 dispersions showed no particular features at $50^{\circ} \mathrm{C}$.

2) HYL-dispersions prepared at $40^{\circ}, 50^{\circ}$, and $60^{\circ} \mathrm{C}$ showed rheopexy properties at $40^{\circ}$ and $50^{\circ} \mathrm{C}$.

3) $\eta^{*}$ vs. time curves of HYL-dispersions at $\omega=0.1 \mathrm{rad} / \mathrm{s}$ indicated complex viscosity in the rheopexy region to increase with decrease in temperature owing to liquid crystalline formation of a bilayer in HYL.

4) Based on the time-dependence of complex viscosity $\left(\eta^{*}\right)$ for HYL-dispersions as determined from shear-jump and change in the liquid crystalline bilayer of HYL, the method for flocculation was elucidated.
\end{abstract}

Key words: lecithin, rheology, shear-jump, viscosity, bilayer

\section{1 はじめに}

レシチンは動・植物, 酵素, 細菌に広く分布してい る天然の両親媒性化合物である (1)。レシチンは生体 膜の主要な構成成分の一つであるほか, 血清コレステ ロールの上昇抑制効果, 肝機能改善効果, 脂肪抢よび 脂溶性ビタミンの吸収促進効果等の生理活性物質とし ての機能 $(2,3)$ を有するほか, 食品用乳化剂, リポ ソーム製剤，リピッドナノスフェア製剤をはじめ化粧 品用の保湿剤として利用されている $(4,5)$ 。また, レ シチンの界面化学的特性の改善（親水性打よび乳化力） を目的として，レシチンの化学修飾が試みられている。 例えば，アセチル化レシチン，部分加水分解レシチン， ヒドロキシ化レシチンの誘導体が合成されている（6-
9)。

水中でのレシチンの溶解挙動に注目すると, レシチ ンはほとんど水に溶解せず, 膨潤し, ゲルやラメラ相 液晶のような分子集合体を形成する。そして，この様 な分子集合体の形成はレシチンの乳化能やその分散液 のレオロジー挙動と重要な関係がある（10-16）。しか し, レシチンのラメラ相液晶の形成性は水分との相互 作用 $(17-22)$ ， ゲルー液晶転移温度（23-27）等の要 因に強く影響されることが報告されているが，水和熟 成温度による影響についてはほとんど系統的に報告さ れていない。

本論文では，精製した水素添加卵黄レシチン（以下 HYL と略す）分散液のレオロジー挙動に対する水和熟 成温度の影響を明らかにすることを目的とした。

* Correspondence to: Teruo Horiuchi, Material Science Research Center, Lion Corporation, 13-12, Hirai 7-Chome, Edogawa-ku, Tokyo 132-0035, JAPAN 


\section{2 実験}

\section{$2 \cdot 1$ 試料}

水素添加卵黄レシチン [HYL]は Table 1 に示す精製品 (キューピー(株)製)をそのまま用いた。

\section{$2 \cdot 2$ 分散液の調製}

水素添加卵黄レシチン [HYL]分散液の調製は薄膜法に 準拠して行った。即ち, $5 \mathrm{~g}$ の HYL 粉末をナス型フラ スコに採取し，これに所定量のエタノールを添加し， 良く攪拌しながら HYL 粉末を完全に溶解させた。次に エバポレーターを用い, 減圧下でエタノールを除去し， HYLの薄膜をナス型フラスコの器壁に生成させた。こ れに $95 \mathrm{~g}$ の蒸留水を添加し，良く膨潤させた後，攪挥 しながら HYL 膜を均一に分散させ， 5 wt \%の HYL 分 散液を得た。この分散液を 40,50 , および $60^{\circ} \mathrm{C}$ の恒温槽 に一昼夜静置させ，完全に熱平衡状態にした。そして， 一昼夜静置後, それぞれの平衡温度で超音波照射器 （W-113, Hobada）を用いて 5 分間超音波照射し分散さ せたものを試料とした。

\section{$2 \cdot 3$ 測定}

$2 \cdot 3 \cdot 1$ 液晶の観察

HYL 分散液の分散打よび会合状態の観察は偏光顕微 鏡（BH 型,オリンパス製）を用いて室温で観察した。

$2 \cdot 3 \cdot 2$ 示差熱量測定 (DSC)

HYL 分散液のゲルー液晶転移温度は $5 \mathrm{wt} \% \mathrm{HYL}$ 分散
液を用い，示差熱量計（Seiko DSC-120, 昇温速度： $1^{\circ}$ C/min）を用いて測定した。DSC チャートよりゲルー 液晶転移温度 $\left(T_{\mathrm{m}}\right)$ を求めた結果, $T_{\mathrm{m}}=48.59^{\circ} \mathrm{C}$ であ った。

$2 \cdot 3 \cdot 3$ レオロジー測定

HYL 分散液の粘弾性スペクトルは振動型レオロジー 測定装置（HAAKE RheoStress 50）を用い，振動周波数 および温度の関数として測定した。

本装置の特徵は Fig.1 に示すように応力とひずみと の関係から分散液について, 次のようなことがわかる ことである。すなわち, 試料の分散液に正弦ひずみを 加えると, 完全弾性体（実線）では応力とひずみとが 同位相となり，その間に遅れを生じないが，粘性体 (点線) では応力がひずみに先行し，両者の間に $90^{\circ}$ の 位相差を生じる。そして, 界面活性剂の濃厚分散液 （28）や水溶性高分子溶液（29）等の粘弾性体（破線） では応力とひずみの関係は完全弾性体と粘性体の中間 の性質を示す。

粘弾性体の各種レオロジーパラメーターは次式で与 えられる(30)。

$G^{*}=\tau o / \gamma_{O}=G^{\prime}+i G^{\prime \prime}$

$G^{\prime}=G^{*} \cos \delta$

$\mathrm{G}^{\prime \prime}=G^{*} \sin \delta$

Table 1 Composition of Hydrogenated Yolk Lecithin.<smiles>[X]OP(=O)([O-])OCC(COC([R])=O)OC([R])=O</smiles>

$\mathrm{R}_{1}, \mathrm{R}_{2}=\mathrm{CH}_{3}\left(\mathrm{CH}_{2}\right)_{\mathrm{n}} ; \mathrm{X}=$ Choline or Ethnolamine

\begin{tabular}{l|c}
\hline Phospholipids & Distribution(\%) \\
phosphatidylcholine & 82.6 \\
phosphatidylethanolamine & 15.2 \\
others & 2.2 \\
\hline Fatty acids $\left(\mathrm{R}_{1}\left(\right.\right.$ or $\left.\left.\mathrm{R}_{2}\right)-\mathrm{CO}-\right)$ & \\
$\mathrm{C}_{14}$ & $\mathrm{~N} . \mathrm{D}$ \\
$\mathrm{C}_{16}$ & $29.7(\%)$ \\
$\mathrm{C}_{18}$ & 54.6 \\
$\mathrm{C}_{20}$ & 6.7 \\
$\mathrm{C}_{22}$ & 8.7 \\
others & 0.3 \\
\hline
\end{tabular}




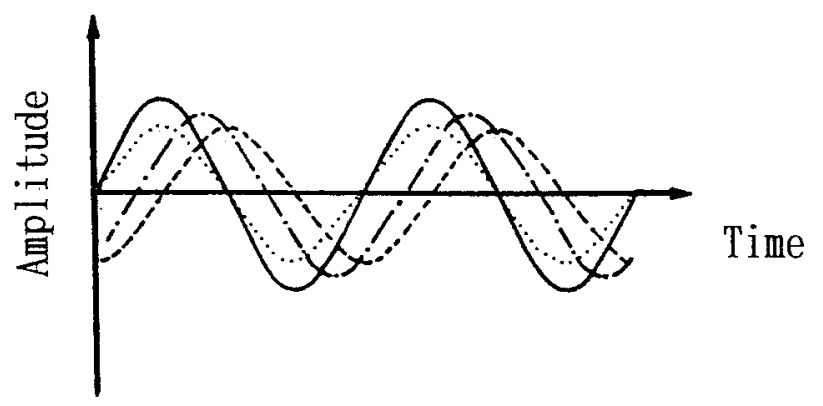

Fig. 1 Phase Relationship of $\operatorname{Stress}(\tau)$ and $\operatorname{Strain}(\gamma)$. Sine wave strain applied to one of the element( (...). Stress for an elastic material(-), purely viscous material(----), and a viscoelastic material(-.- ).

$\eta^{*}=G^{*} / \omega$

ここで, $G^{*}:$ 複素弾性率 (complex modulus), $\tau_{o}$ : 応力 (stress amplitude), $\gamma_{o}:$ ひずみ(strain amplitude), $G^{\prime}$ : 貯蔵弾性率 (elastic modulus), G"：損失弾性率 (loss modulus), $i$ : 虚数単位 (imaginary constant), $\delta$ : 位相角 のずれ (phase angle shift), $\eta^{*}:$ 複素粘性率 (complex viscosity), $\omega$ : 振動周波数 (oscillation frequency) である。
またダンピング $(\tan \delta)$ は損失弾性率 $\left(\mathrm{G}^{\prime \prime}\right)$ と貯蔵弾性率 $\left(G^{\prime}\right)$ の比で応力のひずみの間の位相角のずれとして,

$\tan \delta=G^{\prime \prime} / G^{\prime}$

によって与えられる。

\section{$2 \cdot 3 \cdot 4$ 粒子径の測定}

HYL 分散液中の分散粒子径の測定は BI-90 サブミク ロンパーティクルサイザー（Brookhaven Instruments Co.）を用いて, 温度の関数として測定した。

\section{3 結果および考察}

\section{$3 \cdot 1 \mathrm{HYL}$ 分散液の顕微鏡・偏光顕微鏡写真像}

HYL 分散液を $40,50,60^{\circ} \mathrm{C}$ のれれぞれの恒温槽で一昼 夜静置し，十分に熱平衡状態にしたのち，それぞれの 平衡温度で超音波照射を行い，調製した HYL 分散液の 分散状態打よび分子集合状態を光学顕微鏡打よび偏光 顕微鏡で観察した。その結果を Fig.2に示す。

Fig.2 に示すように HYL のゲルー液晶転移温度 $\left(T_{\mathrm{m}}\right)$ 以下の $40^{\circ} \mathrm{C}$ で調製した分散液（HYL-40）の光学顕微鏡 像は油滴状の凝集物が散在し, 分散が不十分な状態で あった。一方， $T_{\mathrm{m}}$ 近傍の $50^{\circ} \mathrm{C}$ および $T_{\mathrm{m}}$ 以上の $60^{\circ} \mathrm{C} て ゙$

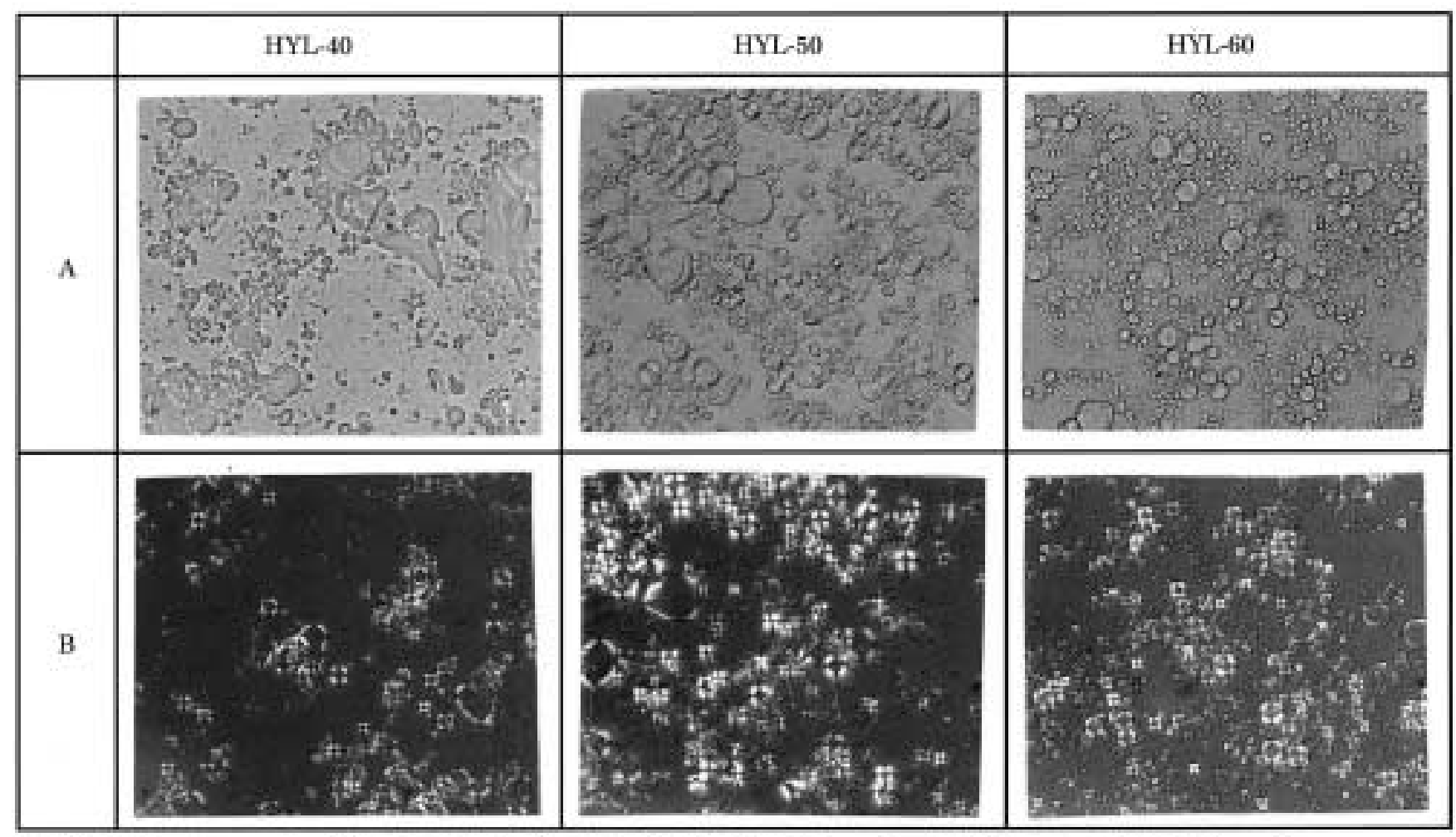

Fig. 2 Optical Micrograms with and without Polarized Light for HYL Dispersions. 
調製した HYL-50 および HYL-60 分散液はいずれも HYL-40 分散液で観察された油状の凝集物はほとんどな く, また水和熟成温度が高いものほど, 均一であった。 一方, これらの HYL 分散液の偏光顕微鏡観察の結果, いずれの場合も十字ニコル像が観察できたことから， HYL 分散粒子は水に膨潤し, ニート相液晶を形成して いると思われる。しかし， $T_{\mathrm{m}}$ 以下の $40^{\circ} \mathrm{C}$ で調製した HYL-40 分散液のニート相液晶の形成性は $T_{\mathrm{m}}$ 近傍の $50^{\circ} \mathrm{C}$ および $T_{\mathrm{m}}$ 以上の $60^{\circ} \mathrm{C} て ゙$ 調製した HYL- 50 および HYL-60 分散液に比べて低い。この事から, HYL 分散液 調製は HYL 分子のゲルー液晶転移温度以上で十分に水 和熟成させ，分散することが重要である事を示唆して いる。

\section{$3 \cdot 2$ 熟成温度の異なる HYL 分散液の平均粒子径の 温度依存性}

Fig. 3 に熟成温度の異なる HYL 分散液（HYL-40, -50 および-60）の平均粒子径の温度依存性を示す。

Fig. 3 から明らかなように, $45^{\circ} \mathrm{C}$ 以上では, 各分散 液の平均粒子径は約 $50 \mathrm{~nm}$ で, 熟成温度によらずほぼ 一定であった。しかし， $45^{\circ} \mathrm{C}$ 以下では，測定温度が低 下するにつれて, HYL-60 分散液の平均粒子径は著しく 増加するが，HYL-40 および HYL-50 分散液の平均粒子 径はわずかに増加するにすぎなかった。

レシチンのような両親媒性分子は温度が上昇しても 水に対しほとんど溶解しない。従って, HYL-60の分散

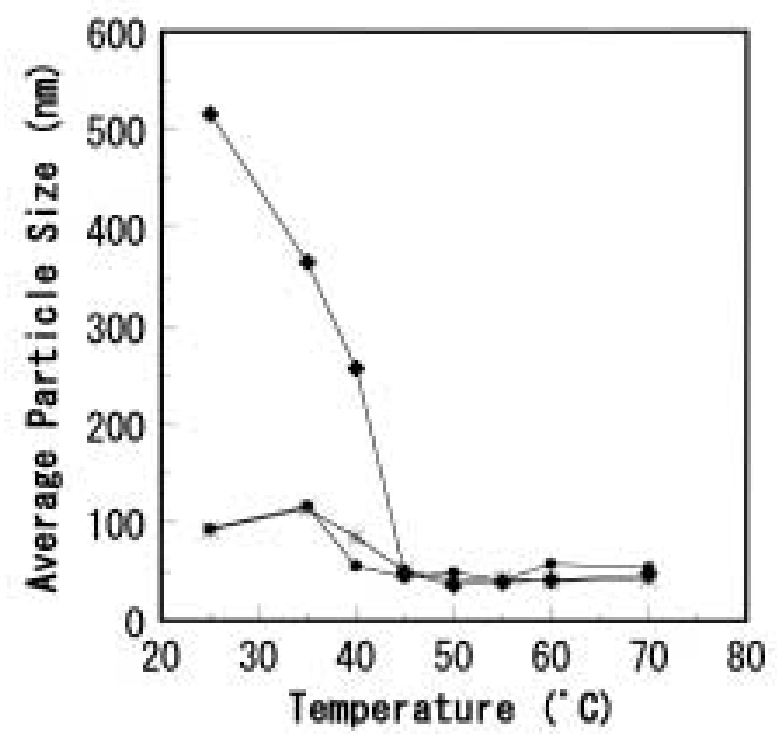

Fig. 3 Temperature-dependence of Average Particle Size of HYL-dispersions which Were Prepared at Various Incubation Temperatures. Symbols: ; HYL-40, * ; HYL-50, $\diamond$ HYL-60.
液の粒子径が低温になるほど大きくなった理由は以下 のように考えられる。 $T_{\mathrm{m}}$ 以上の $60^{\circ} \mathrm{C} て ゙$ 調製した $\mathrm{HYL}$ 60 分散液中の粒子表面は液晶状態であるのに対し, $T_{\mathrm{m}}$ 以下の $40^{\circ} \mathrm{C}$ で調製し HYL-40 分散液の粒子表面はゲ ル状態にある。液晶状の HYL 分散液中の HYL 分散粒 子間の合一速度はゲル状の HYL-40より速いと思われ る。この知見はジミリストイルホスファチジルコリン （DMPC）で乳化したへキサデカンエマルション粒子の 合一速度の結果からも支持される（31）。また, Reddy （32）らは流動パラフィンを乳化剤に triethanolamine oleate を用い乳化したエマルション粒子の $\zeta$ 電位が温 度が上昇すると低くなることを報告している。従って， 高い水和熟成温度で調製した場合, HYL 分散粒子表面

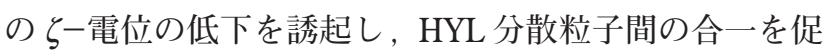
進したものと思われる。

\section{3·3 HYL 分散液の流動曲線の温度依存性}

Fig. 4 に HYL-40 分散液の振動周波数に対する複素粘 性率 $\left(\eta^{*}\right)$ の温度依存性を示す。

Fig. 4 に示した $40^{\circ} \mathrm{C}$ の流動曲線は熱平衡状態におけ るものである。振動周波数が $10 \mathrm{rad} / \mathrm{s}$ までは HYL-40 分散液の複素粘性率は振動周波数に依存せず，ほぼ一 定で, ニュートン流動を示した。しかし，振動周波数 が $10 \mathrm{rad} / \mathrm{s}$ 以上になると, 振動周波数に比例して, そ の複素粘性率は急激に上昇し, ダイラタント流動様の 粘度挙動を示した。これはゲル状態の HYL-40 分散液が せん断力により変形し, せん断誘起構造を構築したも

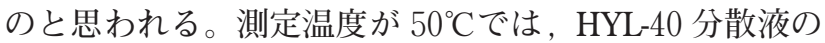
複素粘性率が著しく増加した。この現象は HYL-40 分散 液のゲルー液晶転移温度と符合しているように見える。

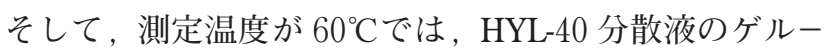
液晶温度以上であるにもかかわらず，HYL-40 分散液の 複素粘性率は著しく減少し, ほほ $40^{\circ} \mathrm{C}$ の時と同じ流動 曲線を示した。これは単に物理的な平衡温度になって も, HYL-40 分散液中の HYL 2 分子膜の膨潤が十分で ないため, 水素結合による水和構造が破壊され, 結果 的に $40^{\circ} \mathrm{C}$ での HYL-40 分散液の流動曲線と同じ挙動を 示したものと思われる。一方, $25^{\circ} \mathrm{C}$ で測定した HYL-40 分散液の複素粘性率が高くなった原因は HYL-40 分散液 の分散状態が不十分であり, 温度低下に伴い, HYLの 油状の凝集物により凝集構造を形成し, 増粘したもの と思われる。

Fig. 5 に HYL-50 分散液の振動周波数に対する複素粘 性率の温度依存性を示す。

Fig. 5 に示すように, $50^{\circ} \mathrm{C}$ の熱平衡状態における HYL-50 分散液の流動曲線は Fig. 4 に示した HYL-40 分 散液の測定温度 $40^{\circ} \mathrm{C}$ の場合と殆ど同じであった。すな わち, 振動周波数が $10 \mathrm{rad} / \mathrm{s}$ までは, その複素粘性率 


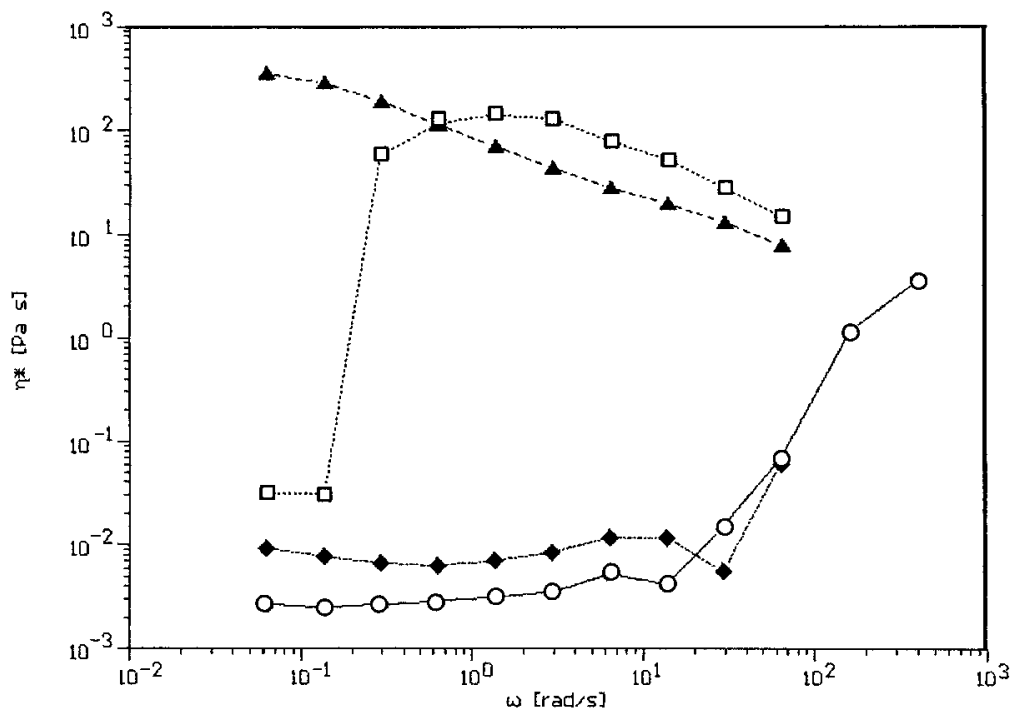

Fig. 4 Plots of Complex Viscosity $\left(\eta^{*}\right)$ of HYL-40 Dispersion vs. Oscillation Frequency $(\omega)$ for Various Temperatures. Concentration of HYL-40 dispersion: $5 \mathrm{wt} \%$.

Measuring temperature: $\square ; 25^{\circ} \mathrm{C}, \bigcirc ; 40^{\circ} \mathrm{C}, \boldsymbol{\Delta} ; 50^{\circ} \mathrm{C}, \diamond ; 60^{\circ} \mathrm{C}$.

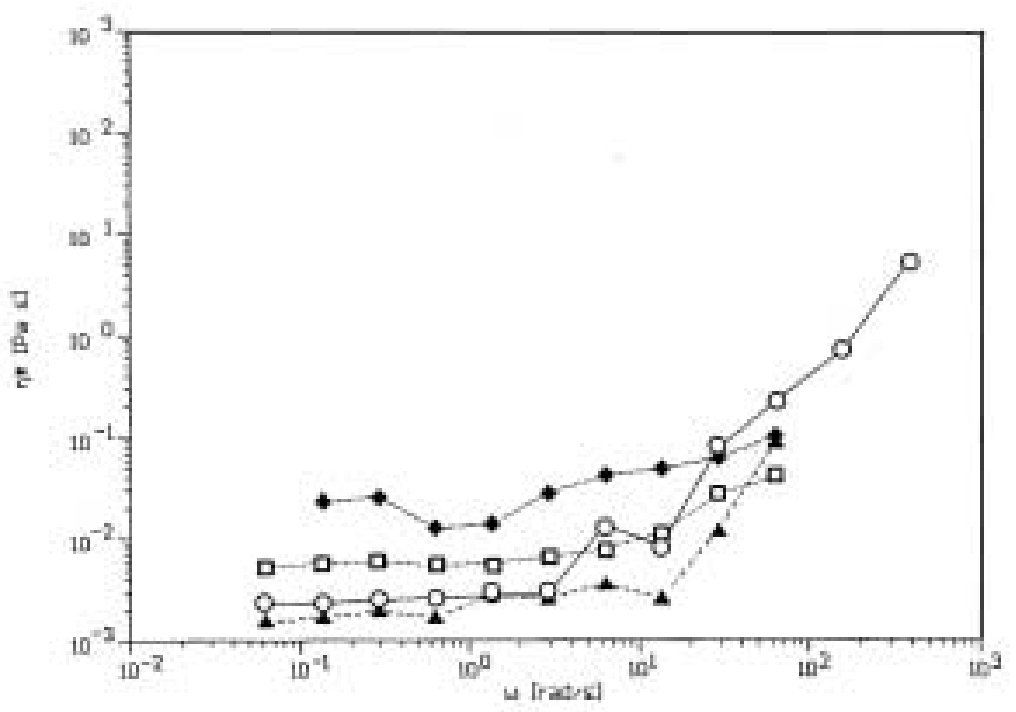

Fig. 5 Plots of Complex Viscosity $\left(\eta^{*}\right)$ of HYL-50 Dispersion vs. Oscillation Frequency $(\omega)$ at Various Temperatures.

Concentration of HYL-50 dispersion: $5 \mathrm{wt} \%$.

Measuring temperature: $\square ; 25^{\circ} \mathrm{C}, \bigcirc ; 40^{\circ} \mathrm{C}, \boldsymbol{\Delta} ; 50^{\circ} \mathrm{C}, \diamond ; 60^{\circ} \mathrm{C}$. 
は振動周波数に関係無く, 1 2 $2 \times 10^{-3} \mathrm{~Pa} \cdot \mathrm{s}$ でほぼ一定 で, ニュートン流動の挙動を示した。そして, 振動周 波数が $10 \mathrm{rad} / \mathrm{s}$ 以上になると, HYL-50 分散液の複素粘 性率は振動周波数と共に急激に増加し，せ九断誘起構 造を示した。これは HYL-50 分散液が HYL のゲルー液 晶転移温度近傍で調製されたため, HYLの膨潤が十分 におこり, 水に不溶な HYL の液晶 2 分子膜の分散粒子 が形成されてしまうと，HYLは水にほとんど溶解しな いため, 凝集や合一が起こりにくく, 流動曲線を測定 するときの温度を変化させても，ほぼ一定の曲線を示 したものと思われる。

Fig. 6 に HYL-60 分散液の振動周波数に対する複素粘 性率の温度依存性を示す。

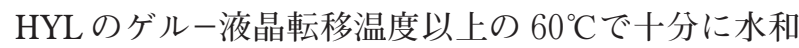
させて調製した HYL-60 分散液は水和した HYL 分散粒 子間で 3 次元的な凝集構造が形成される。しかし， $60^{\circ} \mathrm{C}$ では水素結合に基づくこの凝集構造が熱運動によ り不安定化し, 流動性が増すため, 測定温度 $60^{\circ} \mathrm{C} に$ 打 ける HYL-60 分散液の複素粘性率は測定温度 $50^{\circ} \mathrm{C}$ に比 べて低下する。そして, 測定温度がさらに低下して, $40^{\circ} \mathrm{C}$ になると, 高振動周波数領域で HYL-60 分散液の複 素粘性率は高い值を示した。この理由は HYL-60 分散液 中の 2 分子膜中に $60^{\circ} \mathrm{C}$ での状態が残存したためと思わ れる。しかし, 系の温度が $25^{\circ} \mathrm{C}$ までに低下すると, こ の過冷状態が破壊されて，HYL-40のときと同じ分散状 態になったと思われる。
以上, HYL 分散液の複素粘性率と振動周波数と熟成 温度と測定温度との観点から, 以下のことが結論され る。

$\mathrm{HYL}$ のゲルー液晶転移温度以下の $40^{\circ} \mathrm{C}$ と以上の $60^{\circ} \mathrm{C}$ で一昼夜十分に熱平衡状態にさせてから，それぞれの 温度で超音波照射により分散させ調製した HYL 分散液 の複素粘性率はいずれの場合も測定温度 $50^{\circ} \mathrm{C}$ で極大值 を示した。そして，この複素粘性率を示す温度は HYL のゲルー液晶転移温度と良く一致した。一方, HYLの $T_{\mathrm{m}}$ 近傍で, 一昼夜十分に熱平衡状態にした後, $50^{\circ} \mathrm{Cで}$ 超音波照射を行い調製した HYL-50 分散液の流動曲線は 測定温度に関係なくほぼ同じ $\eta^{*} \sim \omega$ 曲線を示した。

\section{$3 \cdot 4 \mathrm{HYL}$ 分散液の複素粘性率の時間依存性}

HYL 液晶 2 分子膜の形成性に対する熟成温度の影響 を明らかにするため, 振動周波数 $\omega=0.1 \mathrm{rad} / \mathrm{s}$ におけ る HYL 分散液の複素粘性率 $\left(\eta^{*}\right)$ の時間変化を測定し た。

Fig. 7 から明らかなように, HYL 分散液の複素粘性 率はその熟成温度によらず，いずれの場合も測定温度 40 および $50^{\circ} \mathrm{C} て ゙$, 時間とともに増加し, レオペクシー 挙動を示した。そして, 約 5 分後, 一定の複素粘性率 となった。しかし, 測定温度が $60^{\circ} \mathrm{C}$ の時, HYL 分散液 の複素粘性率は 30 秒後に一定值となり, しかもその值 は小さかった。また HYL-40 分散液の場合, 測定温度 $25^{\circ} \mathrm{C}$ で, 複素粘性率は 30 秒まで, 減少し, その後ほぼ

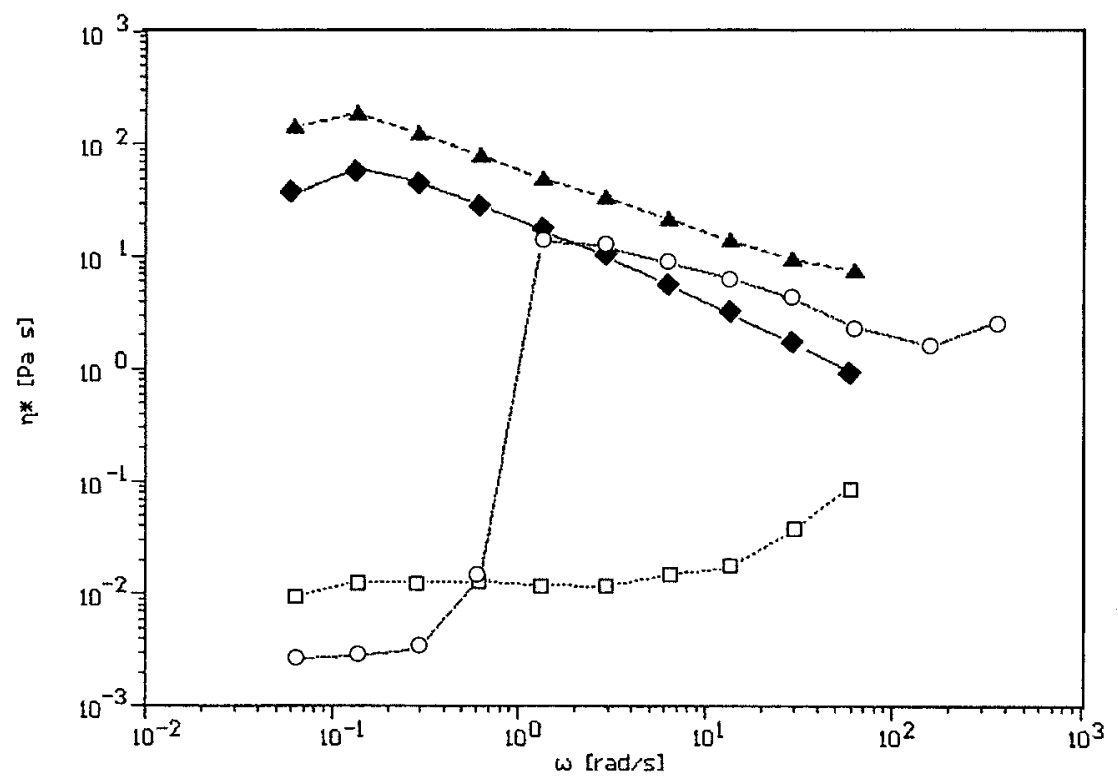

Fig. 6 Plots of Complex Viscosity $\left(\eta^{*}\right)$ of HYL-60 Dispersion vs. Oscillation Frequency $(\omega)$ at Various Temperatures. Concentration of HYL-60 dispersion: $5 \mathrm{wt} \%$. Measuring temperature: $\square ; 25^{\circ} \mathrm{C}, \bigcirc ; 40^{\circ} \mathrm{C}, \boldsymbol{\Delta} ; 50^{\circ} \mathrm{C}, \diamond ; 60^{\circ} \mathrm{C}$. 

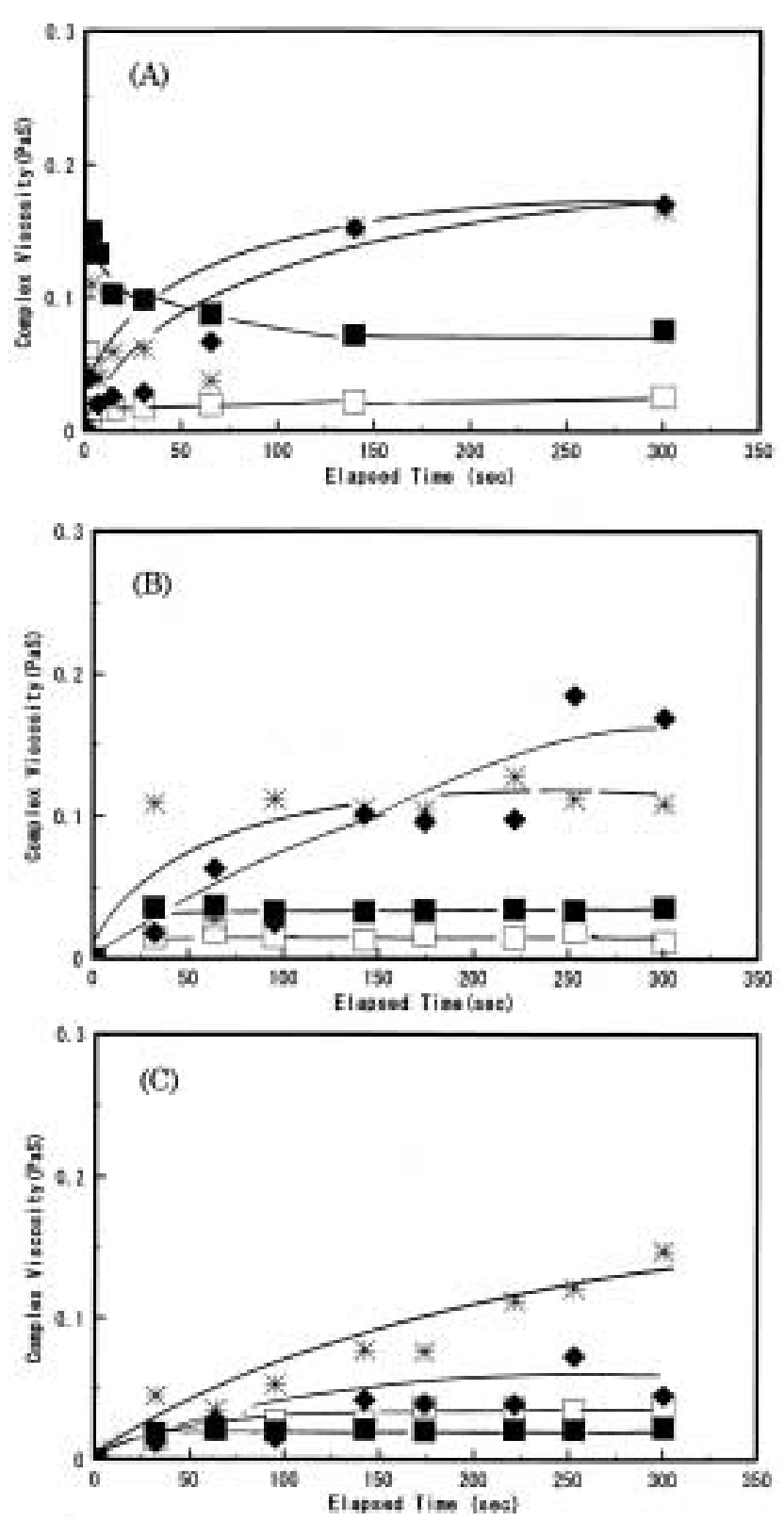

Fig. 7 Time Dependence of Complex Viscosity $\left(\eta^{*}\right)$ for Hydrogenated Yolk Lecithin Dispersions, which Were Prepared at Various Incubation Temperatures, Were Measured as a Function of Temperature. Concentration of each HYL-dispersion: $5 \mathrm{wt} \%$.

(A) HYL-40 dispersions, (B) HYL-50 dispersions, (C) HYL-60 dispersions.

Measuring Temperature: $\square ; 25^{\circ} \mathrm{C}, \boldsymbol{\nabla} ; 0^{\circ} \mathrm{C}, *$; $50^{\circ} \mathrm{C}, \square ; 60^{\circ} \mathrm{C}$

一定值を示した。

Fig. 8 に振動周波数 $\omega=0.1 \mathrm{rad} / \mathrm{s}, 5$ 分後の各 HYL 分散液の複素粘性率 $\left(\eta^{*}\right)$ と測定温度との関係を示す。
HYL 分散液の複素粘性率はいずれの場合も HYLのゲ ルー液晶転移温度に対応する $40 \sim 50^{\circ} \mathrm{C}$ で極大值を示す 曲線となった。しかし，その曲線のプロファイルは HYL 分散液の調製時の水和熟成温度により異なるパ ターンを示した。

Fig. 7 に示したように, HYL 分散液のレオペクシー の発現挙動は熟成温度, 測定温度によって著しく異 なった。レオペクシーを示した領域に打いて，その複 素粘性率の増加速度を求めるため, Fig. 7 の結果を 1 次反応式で近似した。その一例を Fig. 9 に示す。

Fig. 9 に示すように, $\log \eta^{*} \sim t$ (時間) の関係は良 い直線関係を示した。各直線の傾きからレオペクシー を示した領域での複素粘性率の増加速度を求めた。Fig. 10 はその複素粘性率の増加速度と測定温度の関係を示 す。

Fig. 10 から明らかなように, レオペクシーを示す領 域での複素粘性率の増加速度が極大值を示す温度はい

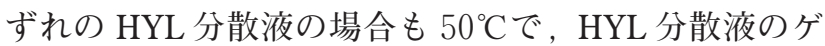

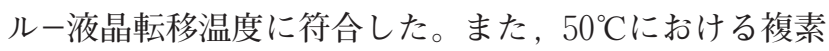
粘性率の増加速度は熟成温度が $40^{\circ} \mathrm{C}>50^{\circ} \mathrm{C}>60^{\circ} \mathrm{C}$ の順 序であった。これらの事から，レオペクシーを示す領 域での複素粘性率の増加速度は HYL 液晶 2 分子膜の形 成性に基づくもので, 熟成温度が低いものほど, HYL

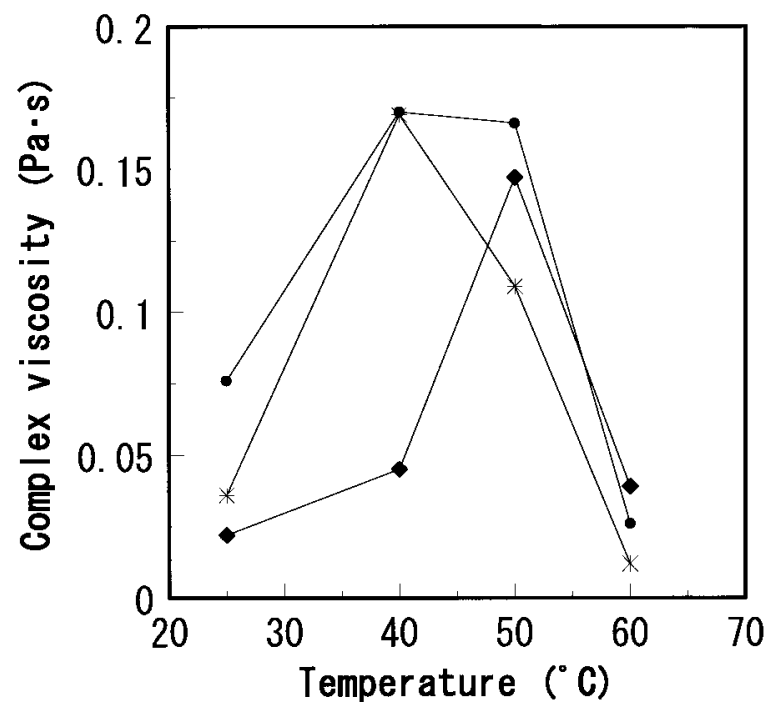

Fig. 8 Relationship between Complex Viscosity $\left(\eta^{*}\right)$ at 5 min and Measuring Temperature for Hydrogenated Yolk Lecithin Dispersions, which Were Prepared at Various Incubation Temperatures.

Oscillation frequency: $0.1 \mathrm{rad} / \mathrm{s}$. Concentration of HYL dispersion: $5 \mathrm{wt} \%$. Symbols: dispersions, *; HYL-50 dispersions, $\diamond$; HYL-60 dispersions. 


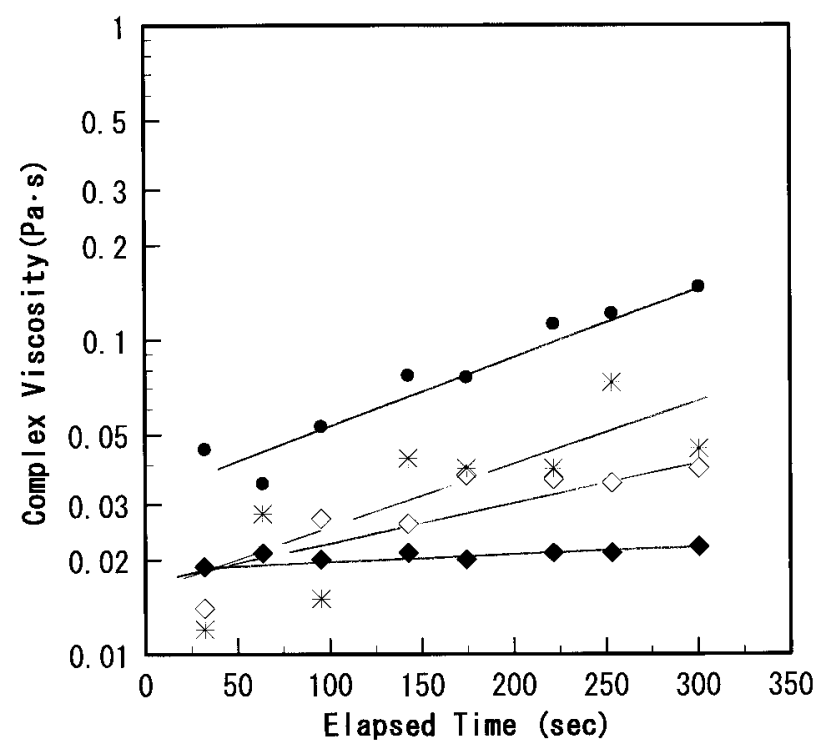

Fig. 9 Plots of Logarithmic of Complex Viscosity $\left(\eta^{*}\right)$ at $\omega$ $=0.1 \mathrm{rad} / \mathrm{s}$ of HYL-60 Dispersions against Elapsed Time at Various Measuring Temperature. Concentration of HYL-60 dispersions: $5 \mathrm{wt} \%$.

Measuring temperature: $>25^{\circ} \mathrm{C}, * ; 40^{\circ} \mathrm{C}$, $50^{\circ} \mathrm{C}, \diamond ; 60^{\circ} \mathrm{C}$.

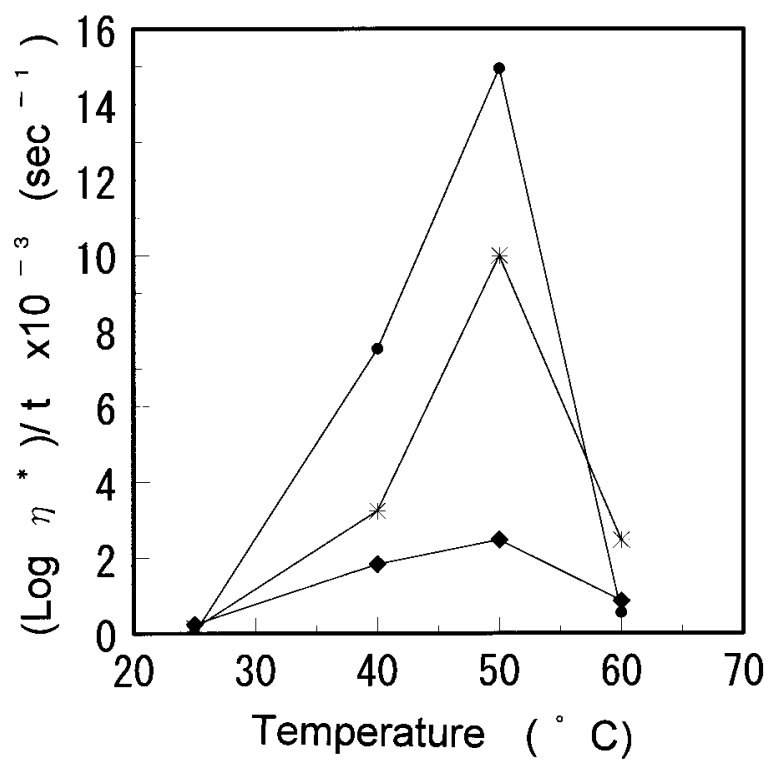

Fig. 10 Relationship between $\left(\log \eta^{*}\right) / \mathrm{t}$ and Temperature for HYL Dispersions, which Were Prepared at Various Incubation Temperatures.

Concentration of HYL dispersions: $5 \mathrm{wt} \%$. Symbols: O HYL-40, *; HYL-50, ; HYL-60.
液晶 2 分子膜の性状が不均一と思われる。しかし， HYL 分散液のゲルー液晶転移温度以上で調製した HYL -50 および HYL-60 分散液の複素粘性率の増加速度に著 しい差異が観察された。この理由については, shearjumpの項で考察する。

\section{$3.5 \mathrm{HYL}$ 分散液の G' および G"に対する測定温度の 影響}

Fig. 11 に熟成温度の異なる HYL 分散液の G’および G"に対する温度打よび振動周波数の影響を示す。

Fig. 11 に示すように, 低振動周波数 $\omega=0.063 \mathrm{rad} / \mathrm{s}$ のとき, HYL 分散液の粘弾性挙動は熟成温度打よび測 定温度によらず，G" $\geqq G^{\prime}$ となり， liquid-like な性質を 示した。一方, 高振動周波数 $\omega=62.8 \mathrm{rad} / \mathrm{s}$ のとき, HYL 分散液は熟成温度および測定温度によらず， $G^{\prime} \geqq$ G"と成り, gel-like な性質を示した。

\section{$3 \cdot 6$ Shear-jump 後の複素粘性率の時間变化}

HYL 分散液調製時の水和熟成温度の違いは HYL 2 分 子膜への水の水和速度もしくは膨潤速度に重要な役割 を果たしていることが示唆された。shear-jump 法によ る HYL 2 分子膜の水和速度（または膨潤速度）に基づ く HYL 分散液の凝集構造の解析を試みた。HYL 分散液 をずり速度に相当する振動周波数 $\omega=0.1 \mathrm{rad} / \mathrm{s}$ で 300 秒印加してから急激に振動周波数を $\omega=1$ または 10 $\mathrm{rad} / \mathrm{s}$ に上昇させた。そして, shear-jump 後の振動周波 数を保持して, 複素粘性率の時間依存性を測定した。

Fig. 12 に一定温度に打ける振動周波数 $\omega=0.1 \mathrm{rad} / \mathrm{s}$ から $\omega=1 \mathrm{rad} / \mathrm{s}$ に shear-jump した後の各 HYL 分散液 の複素粘性率の時間依存性を示す。

Fig. 12-A に示すように, HYLのゲルー液晶転移温度 $\left(T_{\mathrm{m}}\right)$ 以下で調製した HYL-40 分散液は振動周波数が $\omega=0.1 \mathrm{rad} / \mathrm{s}$ から $\omega=1 \mathrm{rad} / \mathrm{s}$ に上昇すると, その複素 粘性率は瞬間的に上昇し, 瞬時に降下し約 10 秒後には ほぼ一定の值となった。一方， $T_{\mathrm{m}}$ 以上で調製した HYL50 扎よび HYL-60 分散液の shear-jump 後の複素粘性率 はゆっくりと減少し, チキソトロピー性を示した。し

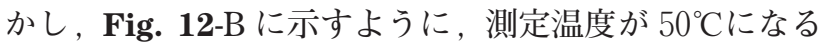
と, 熟成温度を変えて調製した各 HYL 分散液間の差異 は小さくなり, shear-jump 後, 約 220 秒で, 各 HYL 分 散液の複素粘性率は $0.01 \mathrm{~Pa} \cdot \mathrm{s}$ に収斂し, 一定の值を示 した。そして，さらに測定温度が $60^{\circ} \mathrm{C}$ に上昇すると，

Fig. 12-C に示すように, shear-jump 後の各 HYL 分散 液の複素粘性率の差異はほとんど見られなかった。

一方, 測定温度を $40^{\circ} \mathrm{C}$ に固定して, 振動周波数を $\omega=0.1 \mathrm{rad} / \mathrm{s}$ から $\omega=10 \mathrm{rad} / \mathrm{s}$ に増加させた場合, Fig. 13 に示すように, 各 HYL 分散液の複素粘性率の差異 は観察されず, shear-jump 後, それらの複素粘性率は 
瞬時に減少し， 5 から 10 秒後一定值を示した。

以上の結果, shear-jump 後の各 HYL 分散液の複素粘 性率は HYL 分散液を調製するときの熟成温度のほか, 測定温度打よび振動周波数により著しく変化する。 HYL の $T_{\mathrm{m}}$ 以下で調製された HYL-40 分散液は一定の振 動周波数を系に印加して, 十分に時間が経過すると, 系は定常状態になる。そして，振動周波数を $\omega=0.1$

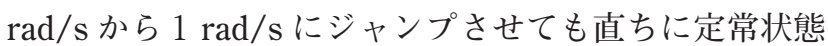

に到達した。これはHYLの 2 分子膜がゲル状態にな り，コリン基部位の解離が抑制され，水分子との相互 作用が少ないため, HYL-40 分散液は所定の振動周波数 に対して定常状態に戻りやすいと思われる。一方， HYL の $T_{\mathrm{m}}$ 以上で調製した HYL-50 および HYL-60 分散 液は HYL2 分子膜がすでに液晶状態であるため, コリ ン基部位が解離し，水和水分子とバルク中の水分子を 通して, HYL 分散粒子間の相互作用が発現し，凝集構

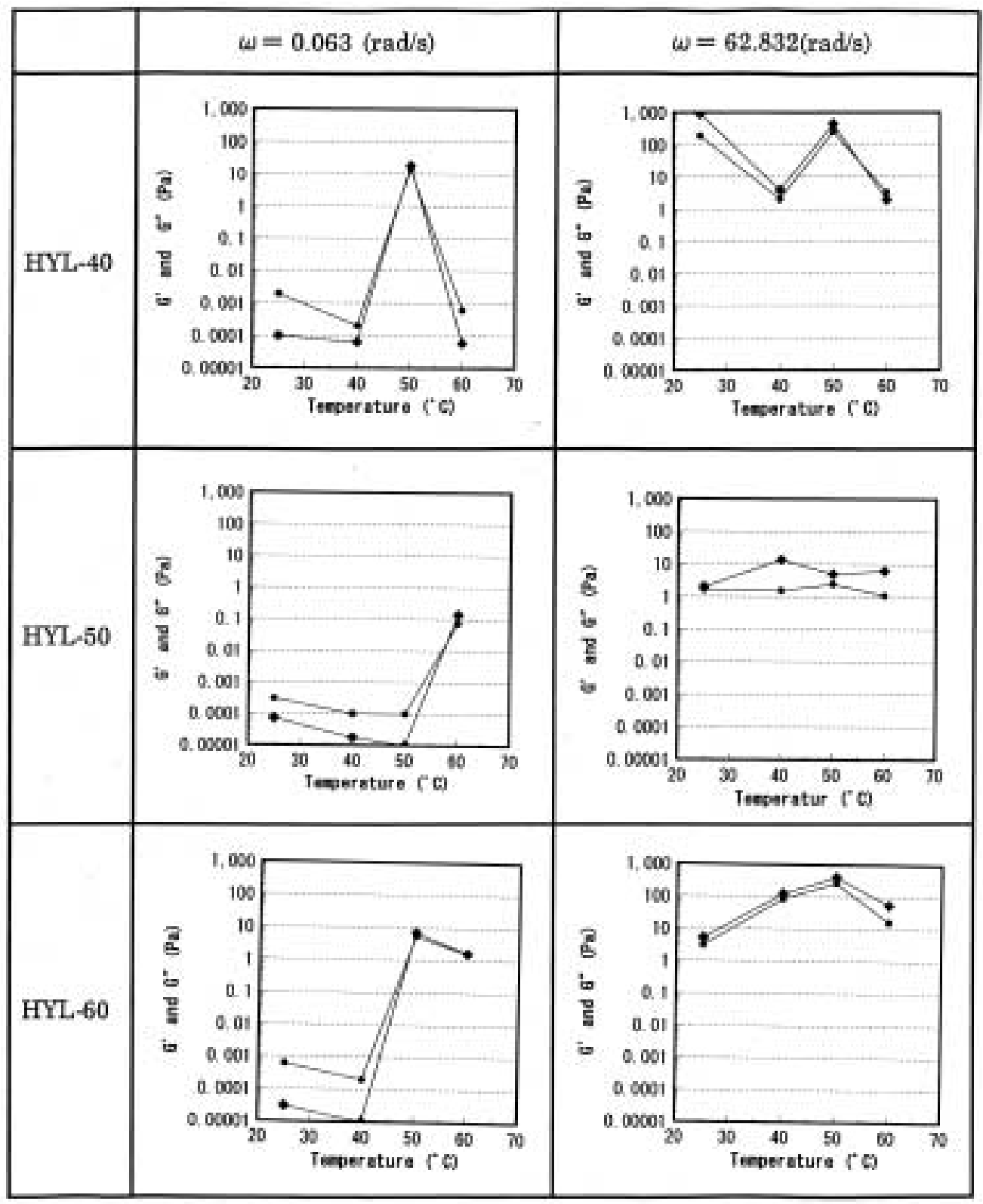

Fig. 11 Plot of G' and G" Parameters at a Given Oscillation Frequency for HYL Dispersions, which Were Prepared at Various Incubation Temperatures. The parameters were measured as a function of temperature. Concentration of HYL dispersions: $5 \mathrm{wt} \%$. 

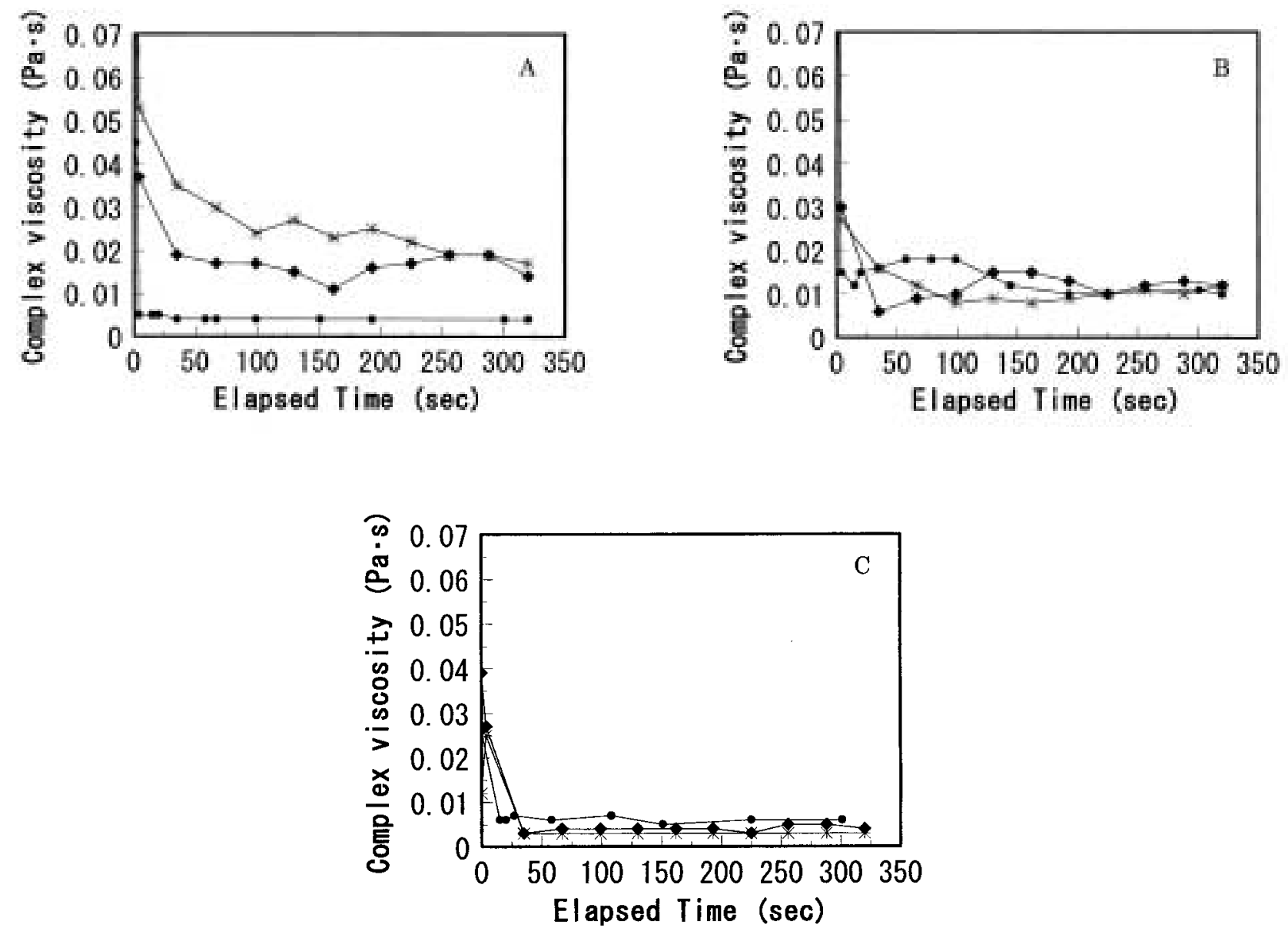

Fig. 12 Time-dependence of Complex Viscosity $\left(\eta^{*}\right)$ for HYL Dispersions, which Were Prepared at Various Incubation Temperatures.

口: incubated at $40^{\circ} \mathrm{C}$ (HYL-40); $\diamond$ : incubated at $50^{\circ} \mathrm{C}$ (HYL-50); $\star$ : incubated at $60^{\circ} \mathrm{C}$ (HYL60). HYL dispsersion was initially subjected to a low steady oscillation frequency at a $\omega$ of 0.1 $\mathrm{rad} / \mathrm{s}$ for $300 \mathrm{sec}$. This was followed by a jump to a higher oscillation frequency of $1 \mathrm{rad} / \mathrm{s}$, that was sustained during the measurements. Concentration of HYL dispersion: $5 \mathrm{wt} \%$.

A: measured at $40^{\circ} \mathrm{C}$; B: measured at $50^{\circ} \mathrm{C}$; C: measured at $60^{\circ} \mathrm{C}$. Incubation temperature: $;$ HYL$40\left(40^{\circ} \mathrm{C}\right), * ; \mathrm{HYL}-50\left(50^{\circ} \mathrm{C}\right), \diamond ; \mathrm{HYL}-60\left(60^{\circ} \mathrm{C}\right)$.

造が構築されていると思われる。この凝集構造が振動 周波数（ずり速度に対応）により破壊され，Fig. 12-A に示す様なチキソトロピー性を示したものと思われる。

Fig. 12-A に示すように, HYL-60 分散液の複素粘性 率に対する減少度は HYL-50 分散液より大きい。これは $60^{\circ} \mathrm{C}$ では水素結合に基づく凝集構造が不安定化し, HYL 2 分子膜の立体配置が変化したたと思われる。ま たは田嶋らのジミリストイルホスファチジルコリン (DMPC) の分散液の低圧比熱容量 $\left(C_{p}\right)$ の温度依存性 （33）扎よびその DMPC 分散液の ESR スペクトルの温 度依存性（34）の研究で報告されているように, HYL 分子にも $T_{\mathrm{m}}$ 以外に臨界温度 $\left(T^{*}\right)$ が存在し, $T_{\mathrm{m}}$ と $T^{*}$ の間で中間相が存在しているためとも考えることがで
きる。

\section{4 結 論}

精製した水素添加卵黄レシチン分散液のレオロジー 挙動に対する熟成温度の影響を強制振動型レオメー ターを用いて検討した。その結果, 以下のことが明ら かになった。

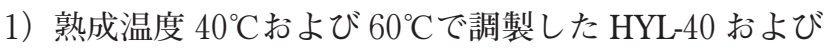
HYL-60 分散液の複素粘性率 $\left(\eta^{*}\right)$ は測定温度 $50^{\circ} \mathrm{C}$ で, HYL の液晶 2 分子膜のゲルー液晶転移温度 $\left(T_{\mathrm{m}}\right)$ を反 映した特性值を示したが，HYL-50 分散液は示さなかっ た。 


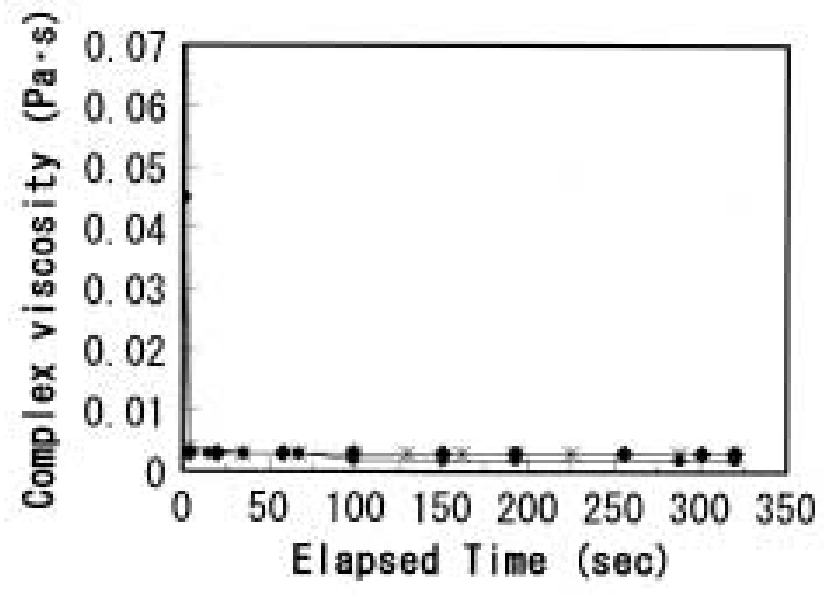

Fig. 13 Time-dependence of Complex Viscosity $\left(\eta^{*}\right)$ for HYL Dispersions, which Were Prepared at Various Incubation Temperatures.

HYL dispersion was initially subjected to a low steady oscillation frequency at a $\omega$ of $0.1 \mathrm{rad} / \mathrm{s}$ for 300 sec. This was followed by a jump to a higher oscillation frequency of $10 \mathrm{rad} / \mathrm{s}$, that was sustained during the measurements at $40{ }^{\circ} \mathrm{C}$. Concentration of HYL dispersion: $5 \mathrm{wt} \%$. Incubation temperature: $\mathrm{HYL}-40\left(40^{\circ} \mathrm{C}\right), *$; HYL-50(50 $\left.{ }^{\circ} \mathrm{C}\right), \diamond ; \mathrm{HYL}-60\left(60^{\circ} \mathrm{C}\right)$.

2）異なる熟成温度で調製した HYL 分散液は，いずれ も測定温度 $40^{\circ} \mathrm{C}$ 打よび $50^{\circ} \mathrm{C}$ でレオペクシー性を示し た。

3）HYL 分散液のレオペクシー領域に打ける複素粘性率 の増加速度は熟成温度が低いほど HYL 液晶 2 分子膜の 形成が遅い。

4） shear-jump 法による HYL 分散液の複素粘性率の時 間変化から，熟成温度によって異なる 2 分子膜の状態 に基づく凝集過程を明きらかにした。

\section{References}

1. Yazawa, K. and Masuzawa, Y. (1991) J. Jpn Oil Chem. Soc., 40, 845-857.

2. Shigematsu, Y. (1992) Development of Functional Lipids, CMC Books, pp. 245-258.

3. Fujikawa, T. (1991) J. Jpn Oil Chem. Soc., 40, 951-958.

4. Narabe, H. (1992) J. Jpn Oil Chem. Soc., 41, 897-902.

5. Narabe, H. (1993) Shokuhin-Kakou-Gijyutsu, 13 (No.3), 222.

6. Kobayashi, K. (1991) J. Jpn Oil Chem. Soc., 40, 379-383.
7. Sato, S. and Nishioka, A. (1979) J. Jpn Oil Chem. Soc., 28, 773780 .

8. Matsuoka, K. (1988) Tech. J. Food Chemistry and Chemicals, 4, 54-60.

9. Egami, (1987) Tech. J. Food Chemistry and Chemicals, 1, 51-54.

10. Rydhag, L. and Wilton, I. (1981) J. Am. Oil Chem. Soc., 58 (No.8), 830-837.

11. Yamano, Y. (1986) J. Jpn Oil Chem. Soc., 35, 478-485.

12. Ishii, F. (1992) J. Jpn Oil Chem. Soc., 41, 787-792.

13. Chiba, K. and Tada, M. (1988) J. Agri. Chem. Soc. Jpn, 62 (No.5), 859-865.

14. Weete, J. D., Betageri, S. and Griffith, G. L. (1994), J. Am. Oil Chem. Soc., 71 (No.7), 731-737.

15. Zhang, F. and Proctor, A. (1997) J. Am. Oil Chem. Soc., 74 (No.7), 869-874.

16. Kabalnov, A., Weers, J., Arlauskas, R. and Tarara, T. (1995) Langmuir, 11, 2966-2974.

17. Kodama, M., Hashigami, H. and Seki, S. (1987) J. Colloid Interfac. Sci., 117 (No.2), 497-504.

18. Ogino, K., Goto, M. and Abe, M. (1988) J. Jpn Oil Chem. Soc., 37, 640-647.

19. Abe, M., Goto, M. and Ogino, K. (1990) J. Jpn Oil Chem. Soc., 39, 351-356.

20. Lafleur, M., Pigeon, M., Pezolet, M. and Caille, J. P. (1989) J. Phys. Chem., 93, 1522-1526.

21. Kodama, M. and Seki, S. (1991) Calorimetry and Thermal Anal., 18 (No.2), 81-88.

22. Kwon, K. O., Abe, M., Ishinomori, T. and Ogino, K. (1994) J. Jpn Oil Chem. Soc., 43, 403-408.

23. Kodama, M., Kuwabara, M. and Seki, S. (1982) Biochim. Bipophys. Acta, 689, 567-570.

24. Kodama, M., Hashigami, H. and Seki, S. (1985) Biochim. Bipophys. Acta., 814, 300-306.

25. Kodama, M. (1986) Thermochimica Acta., 109, 81-89.

26. Mellier, A. (1989) Chem. Phys. Lipids, 51, 23-29.

27. Huang, C. (1991) Biochemistry, 30, 26-30.

28. Smeulders, J. B. A., Mellema, J. and Blom, C. (1992) Phys. Rev., 46 (12), 7708-7722.

29. Goddard, E. D., Leung, P. S. and Padmanabhn, K. P. A. (1991) J. Soc. Cosmet. Chem., 42, 19-34.

30. Tadros, F. and Zsendnai, A. (1990) Colloid Surfac., 43, 95-103.

31. Tajima, K., Horiuchi, T., Imai, Y., Nakamura, A. and Koshinuma, M. (1997) J. Jpn Oil Chem. Soc., 46, 857-866.

32. Reddy, B. R., Rambhau, D. and Dorle, A. K. (1981) Cosmet. and Toilet, 96 (No.5), 45-49.

33. Tajima, K., Imai, Y. and Gershfeld, N. L. (1996) J. Jpn Oil Chem. Soc., 45, 647-653.

34. Tajima, K., Imai, Y., Horiuchi, T., Koshinuma, M. and Nakamura, A. (1996) Langumir, 12, No.26, 6651-6658. 